\title{
Measurement of 3-methylhistidine production in lambs by using compartmental-kinetic analysis*
}

\author{
BY J. A. RATHMACHER, G. LINK AND S. NISSEN $\dagger$ \\ Department of Animal Science, Iowa State University, Ames, Iowa 50011, USA
}

(Received 22 October 1991-Accepted 20 May 1992)

\begin{abstract}
The kineties of 3-methylhistidine (3MH) metabolism in four crossbred lambs were studied. Each lamb was injected with an intravenous dose of $3-\left[^{2} \mathrm{H}_{3}\right]$ methylhistidine $\left(\mathrm{d}_{3}-3 \mathrm{MH}\right)$ and the stable isotope disappearance in plasma and appearance in both urine and muscle were measured. Immediately after the administration of tracer there was a phase of rapid disappearance of tracer from the plasma, which was followed by a more gradual decrease in $d_{3}-3 M H$ from the plasma during the last $4 \mathrm{~d}$ of the experiment. A minimum of three exponentials was required to describe the plasma decay curve adequately. The kinetic model of $3 \mathrm{MH}$ in the whole animal was constructed by using the SAAM/CONSAM computer modelling program. Two different configurations of a three-compartment model are described: (1) a simple three-pool model, in which plasma kinetics were entered into pool 1 out of which they had one undefinable exit; (2) a plasma-urinary three-pool model with two exits, in which the urinary kinetics were entered as an exit out of pool 1 and required a second exit out of pool 3 to produce an adequate fit. In addition, muscle kinetics from biopsies of the longissimus dorsi were entered into either pool 2 or 3 using the plasma-urinary model. Steady-state mass and transport rate values were obtained for each model construct described, and a de novo production rate corresponding to a fractional breakdown rate of myofibrillar protein of approximately $5 \% / \mathrm{d}$ was also calculated. The model predicted that only $15 \%$ of $3 \mathrm{MH}$ was excreted in urine as free $3 \mathrm{MH}$, which is consistent with current knowledge of $3 \mathrm{MH}$ excretion in sheep. The simple three-pool plasma kinetic model, therefore, could be used to estimate, by a relatively simple injection-sampling technique, the extent of muscle protein turnover in lambs.
\end{abstract}

3-Methylhistidine: Kinetic model: Lamb

The primary sequence of actin and of the fast-twitch white myosin in skeletal muscle contains the unique amino acid 3-methylhistidine ( $\mathrm{N}^{t}$-methylhistidine; $3 \mathrm{MH}$; Johnson et al. 1967). During degradation of these muscle proteins free $3 \mathrm{MH}$ is released, but because $3 \mathrm{MH}$ does not have a specific tRNA it is not reutilized for protein synthesis (Young et al. 1972). Instead of being used for protein synthesis, $3 \mathrm{MH}$ is quantitatively excreted in the urine of man, rat, cattle, and rabbit (Young et al. 1972, 1973; Harris et al. 1977; Harris \& Milne, 1981) and, therefore, is thought to be a marker of skeletal muscle protein breakdown. This method depends on quantitative urine collection and accurate measurement of urinary $3 \mathrm{MH}$ and on the assumption that no metabolism of $3 \mathrm{MH}$ occurs in vivo. In most species no metabolism occurs, but in sheep (Harris \& Milne, 1980) a proportion of $3 \mathrm{MH}$ is thought to be retained in muscle as a dipeptide (balenine) of $3 \mathrm{MH}$ and $\beta$-alanine (Harris \& Milne, 1987). In sheep, therefore, urine $3 \mathrm{MH}$ cannot be used to estimate muscle protein breakdown because $3 \mathrm{MH}$ production from muscle is not equal to urinary $3 \mathrm{MH}$ production.

* Journal Paper no. J-14676 of the Iowa Agriculture and Home Economics Experimental Station, Ames, Iowa 50011 ; project no. 2928.

$\uparrow$ For reprints. 
To date, no attempts at integrating tracer and tracee findings into a comprehensive whole-animal kinetic model of $3 \mathrm{MH}$ metabolism in sheep or any other species have been reported. The initial studies showing the inadequacy of $3 \mathrm{MH}$ as an index of muscle protein breakdown in sheep required the intravenous administration of a dose of labelled $3 \mathrm{MH}$, but the decay curve of $\left[{ }^{14} \mathrm{C}\right] 3 \mathrm{MH}$ in plasma was not characterized (Harris \& Milne, 1980). The development of the SAAM/CONSAM computer modelling program (Berman \& Weiss, 1978) has made possible the detailed analysis of tracer observations at multiple sites in the body and has facilitated the interpretation of findings in the context of a physiologically identifiable kinetic model.

The objective of the present study was to characterize the kinetic behaviour of intravenously administered $3-\left[{ }^{2} \mathrm{H}_{3}\right]$ methylhistidine $\left(\mathrm{d}_{3}-3 \mathrm{MH}\right)$ in growing lambs and to develop a kinetic model of $3 \mathrm{MH}$ metabolism based on the analysis of tracer response of plasma, urine excreta, and muscle. This kinetic model will also offer an alternative method for quantifying the de novo $3 \mathrm{MH}$ production rate in vivo, which could be used to estimate the fractional breakdown rate of muscle. The design strategy emphasized detailed observations over time and serves as a reference for comparison with results obtained in other investigations in which the turnover of muscle protein may be altered.

\section{MATERIALS AND METHODS}

\section{Materials}

$\mathrm{d}_{3}-3 \mathrm{MH}$ was purchased from MSD Isotopes, Merck Chemical Division, St Louis, MO, USA (99.5\% isotopic purity). 3MH, 1-methylhistidine (1MH), Jack bean (Canavalia ensiformis DC.) Type IX urease (EC 3.5.1.5) (61000 units/g), and Dowex-50W in the hydrogen form were obtained from Sigma Chemical Co. (St Louis, MO). Acetonitrile and $\mathrm{N}$-methyl-N-( $t$-butyldimethylsilyl) trifluoroacetamide (MTBSTFA) were purchased from Regis Chemical Co., Morton Grove, IL, USA. Ammonium hydroxide, perchloric acid, hydrochloric acid and filter columns were procured from Fisher Scientific, Fair Lawn, NJ, USA. Plastic microinjection sample vials were obtained from Sun Brokers, Inc., Wilmington, NC, USA.

1-Methyl[ $\left[1,1-{ }^{18} \mathrm{O}\right]$ histidine $\left({ }^{18} \mathrm{O}_{2}-1 \mathrm{MH}\right)$ was prepared by exchanging the carboxyl $\mathrm{O}$ in $\mathrm{H}_{2}{ }^{18} \mathrm{O}$ at low $\mathrm{pH}$. To $50 \mathrm{mg}$ dry crystalline $1 \mathrm{MH}, 1 \mathrm{ml} \mathrm{H}_{2}{ }^{18} \mathrm{O}$ was added $\left(96 \%{ }^{18} \mathrm{O}\right.$; Cambridge Isotopes, Woburn, MA, USA). $\mathrm{HCl}$ gas was bubbled through the mixture for 1-2 min. The sample was capped and incubated at $100^{\circ}$ for $30 \mathrm{~min}$, after which it was neutralized with $3 \mathrm{M}-\mathrm{NaOH}$. The resulting neutral amino acid solution was diluted to $100 \mathrm{ml}$, with the final product being $86 \%{ }^{18} \mathrm{O}_{2}-1 \mathrm{MH}$ as assessed by GC-MS.

The cation-exchange columns were prepared by adding $3 \mathrm{ml}$ Dowex-50W cation exchange resin $(50: 50, \mathrm{v} / \mathrm{v})$ in the hydrogen form to filtering columns and washing with four $1 \mathrm{ml}$ portions of $0.01 \mathrm{M}-\mathrm{HCl}$.

\section{Animals and experimental protocol}

Four crossbred (Dorset $\times$ Suffolk) lambs (three wethers and one ewe) weighing 25 (SE 0.5) kg were obtained from a herd at Iowa State University. They were approximately 3-4 months of age. The lambs were fed twice daily on a pelleted diet (Table 1) and had free access to nipple drinkers. At $9 \mathrm{~d}$ before the initiation of the experiment the lambs were transferred to stainless-steel metabolism cages designed for the collection of urine. On the morning of study a catheter was placed into each jugular vein to facilitate tracer injection and withdrawal of blood for each lamb. Approximately $2 \mathrm{~h}$ later a bolus dose of $\mathrm{d}_{3}-3 \mathrm{MH}$, approximately $52 \mu \mathrm{mol}$ in $10 \mathrm{ml}$ sterile saline $(9 \mathrm{~g} \mathrm{NaCl} / \mathrm{l})$, was injected into one catheter and flushed with saline. Blood $(10 \mathrm{ml})$ was collected from the other jugular vein and 
Table 1. Composition of the diet ( $\mathrm{g} / \mathrm{kg}$ total mix, as-fed)

\begin{tabular}{|c|c|c|}
\hline \multicolumn{3}{|l|}{ Ingredient } \\
\hline \multicolumn{2}{|l|}{ Maize, grain cracked } & $450 \cdot 7$ \\
\hline \multicolumn{2}{|l|}{ Oats, grade 2 ground } & $200 \cdot 1$ \\
\hline \multicolumn{2}{|l|}{ Soya-bean meal (expeller) } & $200 \cdot 1$ \\
\hline \multicolumn{2}{|l|}{ Dehydrated lucerne } & $100 \cdot 1$ \\
\hline \multicolumn{2}{|l|}{ Molasses (sugar cane) } & $30 \cdot 0$ \\
\hline \multicolumn{2}{|l|}{ Limestone } & $7 \cdot 5$ \\
\hline \multicolumn{2}{|l|}{ Dicalcium phosphate } & $2 \cdot 5$ \\
\hline \multicolumn{2}{|l|}{ Salt } & $2-5$ \\
\hline \multicolumn{2}{|l|}{ Vitamin premix } & $5 \cdot 0$ \\
\hline \multirow[t]{2}{*}{ Pell-aid* } & & $1 \cdot 5$ \\
\hline & Requirement & Supplied \\
\hline Daily intake $(\mathrm{kg}) \dagger$ & $1 \cdot 58$ & $1 \cdot 58$ \\
\hline Metabolizable energy & & \\
\hline$(\mathrm{MJ}) \dagger$ & $16 \cdot 73$ & $16 \cdot 85$ \\
\hline (Mcal) & $4 \cdot 00$ & $4 \cdot 03$ \\
\hline Crude protein $(\mathrm{N} \times 6.25 ; \mathrm{kg}) \dagger$ & $0 \cdot 22$ & $0 \cdot 27$ \\
\hline Calcium $(\mathrm{g}) \dagger^{\dagger}$ & $7 \cdot 2$ & $8 \cdot 5$ \\
\hline Phosphorus $(\mathrm{g}) \dagger$ & $3 \cdot 4$ & $6 \cdot 1$ \\
\hline
\end{tabular}

transferred to EDTA-coated tubes at $2,7,10,15,45,90,150,210,270,720,1440,2880$, 4320,5760 and $7200 \mathrm{~min}$ post injection. Blood samples were placed directly in an ice bath until they could be centrifuged and plasma collected and stored at $-70^{\circ}$. After the injection of tracer, muscle was taken by needle biopsy $(60-70 \mathrm{mg})$ at $12,60,300,1440$ and $4320 \mathrm{~min}$ from the longissimus dorsi after the area $5 \mathrm{~cm}$ from midline was treated with local anaesthesia. The muscle sample was immediately placed on ice and stored at $-70^{\circ}$. During the first $5 \mathrm{~d}$ of the tracer experiment, consecutive $24 \mathrm{~h}$ total urine outputs were collected. Portions of each urine collection were kept frozen at $-20^{\circ}$. Additional baseline blood, muscle, and urine samples were collected before injection to subtract background enrichment from the experimental samples.

\section{Internal standards}

Because of its structural similarity to $3 \mathrm{MH}$ and its undetectability in the plasma of sheep, $1 \mathrm{MH}$ was used as an internal standard $(50 \mu \mathrm{l} 3540 \mu \mathrm{M}$ stock solution) in the analysis of $3 \mathrm{MH}$ concentration in plasma. But ${ }^{18} \mathrm{O}_{2}-1 \mathrm{MH}(40 \mu \mathrm{l} 2955 \mu \mathrm{M}$ stock solution) was used as the internal standard for the quantification of $3 \mathrm{MH}$ in urine because a significant quantity of $1 \mathrm{MH}$ accumulates in urine.

\section{Analysis of plasma $3 \mathrm{MH}$}

Plasma $(1 \mathrm{ml})$ and $50 \mu 1 \mathrm{MH}$ internal standard $(3.5 \mathrm{~mm})$ were added to a plastic sample tube $(12 \mathrm{ml})$. Perchloric acid (PCA; $1.5 \mathrm{M} ; 3 \mathrm{ml}$ ) was added, and the tube contents stirred using a vortex mixer and centrifuged at $2300 \mathrm{~g}$ for $15 \mathrm{~min}$ at $5^{\circ}$. The supernatant fraction was poured onto a prepared cation-exchange column. After draining through the column the supernatant fraction was rinsed with four $1 \mathrm{ml}$ portions of $0.01 \mathrm{M}-\mathrm{HCl}$ and the washings were discarded. Then, $3 \mathrm{MH}$ and internal standard $(1 \mathrm{MH})$ were eluted from the column 
with four $1 \mathrm{ml}$ washes of $\mathrm{NH}_{4} \mathrm{OH}(250 \mathrm{ml} / \mathrm{l})$ into a $20 \mathrm{ml}$ scintillation vial. The eluant was heated to $65^{\circ}$ in a block and dried under a stream of $N_{2}$. When the eluant seemed dry, any remaining water was removed by the sequential addition of two $100 \mu 1$ portions of methylene chloride, drying off samples between each addition. A derivative of the dried sample was prepared for GLC-MS analysis by adding $100 \mu \mathrm{l}$ acetonitrile and $100 \mu 1$ MTBSTFA and incubating overnight at room temperature.

The derivatized sample was transferred into an injection vial and capped. GLC-MS was accomplished by means of a Hewlett-Packard gas chromatograph-mass selective detector (model 5890/5970B). The column used was a $25 \mathrm{~m} \times 0.22 \mathrm{~mm}$ i.d. $\times 0.11 \mu \mathrm{m}$ film thickness, cross-linked methyl silicone gum phase capillary column (HP-1; Hewlett-Packard, Avondale, PA, USA). The injector and the transfer line were set at $285^{\circ}$ and the initial oven temperature at $50^{\circ}$. After splitless injection, the oven was programmed to hold for $0.5 \mathrm{~min}$ and increased (ramp 1) to $240^{\circ}$ at $50^{\circ} / \mathrm{min}$ which was held for $4.1 \mathrm{~min}$, followed by an increase ( $\operatorname{ramp} 2$ ) to $300^{\circ}$ at $50^{\circ} / \mathrm{min}$, which was held for $1 \mathrm{~min}$. The retention times were between 6.5 and $7.5 \mathrm{~min}$ for $3 \mathrm{MH}$ and 7.0 and $8.0 \mathrm{~min}$ for $1 \mathrm{MH}$, depending on column age and exact length. The major ion fragments for $3 \mathrm{MH}$ and $\mathrm{d}_{3}-3 \mathrm{MH}$ were monitored by means of selective ion monitoring. $3 \mathrm{MH}$ was monitored at $238 \mathrm{~m} / \mathrm{z}$ and its stable isotope, $\mathrm{d}_{3}-3 \mathrm{MH}$, at $241 \mathrm{~m} / \mathrm{z}$, whereas $1 \mathrm{MH}$ was detected at $340 \mathrm{~m} / \mathrm{z} .3 \mathrm{MH}$ in plasma was quantified from a linear peak height standard curve. When $\mathrm{d}_{3}-3 \mathrm{MH}$ was used as a tracer, as will be described, it was quantified in plasma in the same manner, that is by subtracting the natural background enrichment $\mathrm{d}_{3}-3 \mathrm{MH} / 3 \mathrm{MH}$ from detected $\mathrm{d}_{3}-3 \mathrm{MH}$.

Standards were prepared by pipetting known quantities of $3 \mathrm{MH}$ from a $50 \mu \mathrm{M}$ stock solution into plastic sample tubes $(12 \mathrm{ml})$ along with $50 \mu \mathrm{l} 1 \mathrm{MH}$ internal standard. Doubledeionized water $(1 \mathrm{ml})$ was added to each standard tube. Because the neutralizing capacity of standards was small compared with that of plasma, the standards were acidified with only $0.25 \mathrm{ml} 1.5 \mathrm{M}$-perchloric acid and treated the same as was the plasma sample.

\section{Analysis of urine $3 M H$}

Unlike plasma, urine contains substantial amounts of $1 \mathrm{MH}$, making $1 \mathrm{MH}$ an impractical internal standard; therefore, ${ }^{18} \mathrm{O}_{2}-1 \mathrm{MH}$ was used as the internal standard with which to quantify $3 \mathrm{MH}$ in urine. Standards were prepared as outlined except that $40 \mu \mathrm{l}^{18} \mathrm{O}_{2}-1 \mathrm{MH}$ was used as the internal standard. A urine sample was prepared by transferring $1 \mathrm{ml}$ to a microfuge tube and removing particulate matter by spinning for $3 \mathrm{~min}$. From this tube, $100 \mu \mathrm{l}$ urine was pipetted into a plastic sample tube $(12 \mathrm{ml})$ with $40 \mu \mathrm{l}$ internal standard. In addition, $1 \mathrm{ml}$ double-deionized water was added to the tube and the contents were acidified with $5 \mu \mathrm{l} 3 \mathrm{M}-\mathrm{HCl}$. The urine sample was stirred with a vortex mixer, poured over a cation-exchange column (prepared as outlined) and allowed to drain. The column was rinsed with four $1 \mathrm{ml}$ washes of $0.01 \mathrm{M}-\mathrm{HCl}$ and eluted with four $1 \mathrm{ml}$ washes of $\mathrm{NH}_{4} \mathrm{OH}$ $(250 \mathrm{ml} / \mathrm{l})$, which were collected in a scintillation vial and dried with a stream of $\mathrm{N}_{2}$ on a heating block at $65^{\circ}$. Once dry, the urea in the sample was hydrolysed with $1 \mathrm{ml}$ urease solution ( $35 \mathrm{mg} / \mathrm{l}$ ) by incubating the sample on a heating block for $2 \mathrm{~h}$ at $37^{\circ}$. The sample was again dried on the heating block, derivatized with $100 \mu l$ acetonitrile and $100 \mu 1$ MTBSTFA and incubated overnight at room temperature. The derivatized sample was transferred into an injection vial and injected in a Hewlett-Packard gas-liquid chromatograph by using the same conditions and ramps as described previously. The retention time for $3 \mathrm{MH}$ was the same in urine as in plasma and exhibited the same mass spectra. ${ }^{18} \mathrm{O}_{2}-1 \mathrm{MH}$ had a retention time similar to that of natural $1 \mathrm{MH}$, but major ions from the mass spectra were $4 \mathrm{~m} / \mathrm{z}$ heavier. $3 \mathrm{MH}$ and $\mathrm{d}_{3}-3 \mathrm{MH}$ were quantified by peak height as explained for plasma analysis except that ${ }^{18} \mathrm{O}_{2}-1 \mathrm{MH}$ replaced $1 \mathrm{MH}$ in the calculations. 


\section{Analysis of free $3 M H$ in muscle}

Approximately $70 \mathrm{mg}$ muscle was transferred into a plastic sample tube $(12 \mathrm{ml})$ with $40 \mu \mathrm{l}$ internal standard. In addition, $1.5 \mathrm{ml}$ double-deionized water was added to the tube, and the contents were homogenized by using a Polytron tissue homogenizer with a $15 \mathrm{~mm}$ stator generator. The homogenization was performed at $15000 \mathrm{rev} . / \mathrm{min}$ for $15 \mathrm{~s}$. The blades of the homogenizer were washed with $0.5 \mathrm{ml}$ double-deionized water and added to the sample tube. PCA $(1.5 \mathrm{M} ; 1 \mathrm{ml})$ was added, and the tube contents were stirred with a vortex mixer and centrifuged at $2300 \mathrm{~g}$ for $15 \mathrm{~min}$ at $5^{\circ}$. The supernatant fraction was poured onto a prepared cation-exchange column. The protein pellet was resuspended twice in $0.5 \mathrm{M}$-PCA and recentrifuged at $2300 \mathrm{~g}$ for $15 \mathrm{~min}$ at $5^{\circ}$. On both occasions, the supernant fraction was poured over a cation-exchange column and allowed to drain. The column was rinsed with four $1 \mathrm{ml}$ washes of $0.01 \mathrm{M}-\mathrm{HCl}$ and eluted with four $1 \mathrm{ml}$ washes of $\mathrm{NH}_{4} \mathrm{OH}$ $(250 \mathrm{ml} / \mathrm{l})$, which were collected in a scintillation vial and then dried with a stream of $\mathrm{N}_{2}$ on a heating block at $65^{\circ}$. A derivative of the sample was prepared and subjected to GLC-MS as described previously.

\section{Kinetic modelling}

Modelling of $3 \mathrm{MH}$ kinetics was done with the SAAM/CONSAM computer program (Boston et al. 1981). Exponential equations were initially fitted to the plasma concentration of $\mathrm{d}_{3}-3 \mathrm{MH}$ time curves to characterize the complexity of the response and to allow for comparisons with other studies. The first step in constructing a compartmental model was to determine the minimum number of compartments and interconnections suitable for the data. Thus, only the plasma kinetic data were used, which were expressed as a proportion of dose $/ \mathrm{ml}$. These findings were used in addition to previous knowledge of $3 \mathrm{MH}$ metabolism in sheep (Harris \& Milne, 1980). Second, this basic model was expanded to include a urinary exit in which values were expressed as a proportion of the dose. The connections between compartments were adjusted to optimize the fit and eventually included a second exit from the model. Finally, the muscle enrichment of $3 \mathrm{MH}$ from the muscle biopsies was incorporated into the model and all values were simultaneously fitted. In addition, steady-state masses and transport rates were calculated for each model, and the de novo production rate calculated could be used to calculate a fractional degradation rate for the myofibrillar proteins. The nomenclature and illustrations used in describing the model are the same as in the SAAM (simulation analysis and modelling) manual (Berman \& Weiss, 1978). Brief definitions of the terms used are given: $L(I, J)$ is the proportion of material transported from compartment $J$ to $I$ per unit time (proportion $/ \mathrm{min}$ ), $R(I, J)$ is transport of tracee (natural 3MH) from compartment $J$ to I per unit time ( $\mathrm{nmol} / \mathrm{min}$ ) under steady-state conditions, $U(I)$ is entry of tracee into compartment I from outside the model per unit time ( $\mathrm{nmol} / \mathrm{min}$ ) (the de novo production of unlabelled $3 \mathrm{MH}$ from breakdown of actin and myosin proteins into intracellular muscle pool under steady-state conditions), $\mathrm{M}(\mathrm{I})$ is mass of tracee (unlabelled $3 \mathrm{MH}$ ) in compartment $\mathrm{I}, \mathrm{K}(\mathrm{I})$ is proportionality constant associated with compartment I. CONSAM assumes that a component number is specified under an H DATa header statement in the input file, and it will automatically multiply the category associated with this component by $\mathrm{K}(\mathrm{I})$ to calculate QC(I). QC(I) is CONSAM's notation for calculated values. Data associated with a component I are called QO(I). K(I) represented the inverse of the space of distribution. The number of compartments in the model is arbitrary and reflects simply the choices of compartment numbers made during the development of the model. 


\section{RESULTS}

\section{Tracer response profiles}

The mean tracer enrichment in plasma and muscle and the percentage recovery of tracer in urine are presented in Table 2 . The $\mathrm{d}_{3}-3 \mathrm{MH}$ values exhibited a typical disappearance pattern (Fig. 1). After the injection of tracer, $d_{3}-3 \mathrm{MH}$ was lost rapidly from the plasma during the first $150-180 \mathrm{~min}$, followed by a transition period through $720 \mathrm{~min}$ in which the decrease in tracer concentration seemed to level off. The final phase was characterized by a gradual decline in tracer during the remaining $5 \mathrm{~d}$ of the kinetic study.

During the preliminary fitting of exponential equations to the plasma kinetic data we found that a minimum of three exponential terms was required to achieve an adequate fit. The exponential equations for individual animals are given below, where $c(t)$ is the concentration of $\mathrm{d}_{3}-3 \mathrm{MH}$ in plasma at time $t$ (min post injection):

$$
\begin{aligned}
& \text { lamb no. 9173: } c(t)=1.36 \exp ^{0.000133 t}+4.02 \exp ^{0.133 t}+0.757 \exp ^{0.00490 t}, \\
& \text { lamb no. 9183:c(t) }=1.47 \exp ^{0.000197 t}+4.44 \exp ^{0.126 t}+0.914 \exp ^{0.00422 t}, \\
& \text { lamb no. 9186:c(t) }=1.57 \exp ^{0.000204 t}+4.13 \exp ^{0.183 t}+1.61 \exp ^{0.00638 t}, \\
& \text { lamb no. 9169:c(t)=1.45 } \exp ^{0.000143 t}+5.84 \exp ^{0.273 t}+1.77 \exp ^{0.00517 t}
\end{aligned}
$$

\section{Model development}

The model developed used linear first-order differential equations; therefore, it is based on the assumption of steady-state kinetics in the animals over the duration of the experiment. No significant differences were seen in individual lamb plasma levels or in urinary production of $3 \mathrm{MH}$ during the duration of the experiment, so the lambs were assumed to be in steady-state. No animal by-products were included in the diet so it was assumed that the only source of natural $3 \mathrm{MH}$ was from the degradation of actin and myosin.

The stages of model development are illustrated in Figs. 2-4 to describe the sequential addition of different metabolic pools; the model configuration is included in an inset in each figure. The first step (Fig. 2) was to describe the plasma kinetic data in terms of a compartmental model. This was a simple three-compartment model in which the plasma data were entered into compartment 1 as a fraction of injected dose $/ \mathrm{ml}$. Compartment 1 was connected in a series with compartments 2 and 3 , and there was one exit from the system from compartment 1 . This plasma model required a minimum of three compartments to produce an adequate fit between the values calculated by the model and the observed data points. Model variables and steady-state masses and transport rates are shown in Table 3 . The plasma curve is characterized by a sharp decline in tracer during the first phase and a more gradual decline during the last $5 \mathrm{~d}$. Steady-state transport rates indicate that there is rapid exchange of $3 \mathrm{MH}(\mathrm{nmol} / \mathrm{min})$ between pools 2 and 3, compared with a slowly turning over pool 3. The average de novo $3 \mathrm{MH}$ production rate $(\mathrm{U}(2))$ for four lambs was 205 (SE 3.6) $\mathrm{nmol} / \mathrm{min}$. The fractional breakdown rate of myofibrillar protein could be calculated in the same manner as Harris \& Milne (1980), assuming that muscle was $35 \%$ of body weight and that protein-bound $3 \mathrm{MH}$ was $0.6 \mu \mathrm{mol} / \mathrm{g}$ muscle. The average de novo production rate into compartment 2 corresponded to an average fractional breakdown rate of $5.4 \% / \mathrm{d}$.

The next stage in the model development was to incorporate the urine kinetic data. We first attempted to include the accumulative urine recovery of $\mathrm{d}_{3}-3 \mathrm{MH}$ tracer as the only exit from compartment 1 . This model was inadequate to describe both the plasma and urine kinetic data, inasmuch as we saw a significant decrease in the plasma sum of squares. This would be expected because only a proportion of the radioactivity was recovered in the urine of sheep after an intravenous dose of $\left[{ }^{14} \mathrm{C}\right] 3 \mathrm{MH}$, whereas a large proportion was retained 
Table 2. Mean tracer response profiles in plasma, muscle and urine of four lambs injected with 52.6 mol 3- $\left[{ }^{2} \mathrm{H}_{3}\right]$ methylhistidine $\left(\mathrm{d}_{3}-3 \mathrm{MH}\right)^{*}$

(Mean values with their standard errors)

\begin{tabular}{|c|c|c|c|c|c|c|}
\hline \multirow{2}{*}{$\begin{array}{c}\text { Period after } \\
\text { dose } \\
\text { (min) }\end{array}$} & \multicolumn{2}{|c|}{ Plasma enrichment $\dagger$} & \multicolumn{2}{|c|}{ Muscle enrichment $\ddagger$} & \multicolumn{2}{|c|}{$\begin{array}{l}\text { Percentage tracer } \\
\text { recovery in urine§ }\end{array}$} \\
\hline & Mean & $\mathrm{SE}$ & Mean & $\mathrm{SE}$ & Mean & $\mathrm{SE}$ \\
\hline 2 & $0 \cdot 181$ & 0.0206 & & & & \\
\hline 7 & $0 \cdot 111$ & 0.0128 & & & & \\
\hline 10 & $0 \cdot 104$ & $0 \cdot 0084$ & & & & \\
\hline 12 & & & 0.020 & 0.0069 & & \\
\hline 15 & $0 \cdot 091$ & 0.0070 & & & & \\
\hline 45 & $0 \cdot 081$ & 0.0007 & & & & \\
\hline 60 & & & $0 \cdot 029$ & 0.0088 & & \\
\hline 90 & $0 \cdot 063$ & 0.0049 & & & & \\
\hline 150 & 0.055 & 0.0048 & & & & \\
\hline 210 & 0.052 & 0.0035 & & & & \\
\hline 270 & 0.050 & 0.0045 & & & & \\
\hline 300 & & & $0 \cdot 024$ & 0.0029 & & \\
\hline 720 & $0 \cdot 039$ & 0.0033 & & & & \\
\hline 1440 & 0.033 & 0.0020 & 0.034 & 0.0074 & 3.41 & $1 \cdot 01$ \\
\hline 2880 & $0 \cdot 025$ & $0 \cdot 0018$ & & & 5.89 & $1 \cdot 45$ \\
\hline 4320 & 0.019 & 0.0009 & 0.018 & 0.0031 & 7.96 & 1.66 \\
\hline 5760 & $0 \cdot 015$ & 0.0003 & & & $9 \cdot 41$ & 1.85 \\
\hline 7200 & $0 \cdot 011$ & 0.0008 & & & 10.80 & $1 \cdot 88$ \\
\hline
\end{tabular}

* For details of procedures, see pp. 744-747.

$\dagger$ Calculated as the background corrected $\mathrm{d}_{3}-3 \mathrm{MH} / 3-$ methylhistidine $(3 \mathrm{MH})$ peak height abundance (ion $241 / 238$ ).

$\$$ Enrichment of tracer in longissimus dorsi biopsies was calculated as the background corrected $\mathrm{d}_{3}-3 \mathrm{MH} / 3 \mathrm{MH}$ peak height abundance (ion 241/238).

$\S$ The percentage $\mathrm{d}_{3}-3 \mathrm{MH}$ accumulating in the urine.

(Harris \& Milne, 1980). We next modified this plasma-urinary model (Fig. 3) to include a second exit from compartment 3, an exit meant to represent an exit into a balenine (Harris \& Milne, 1980, 1987) 'sink' that turns over very slowly or not at all during the time frame of the study. This model, illustrated in Fig. 3, was constructed by including the plasma kinetic data in compartment 1 , and the urinary kinetic data were described by an exit from compartment $1(\mathrm{~L}(10,1))$. With this model we saw close agreement between observed and calculated values for describing both plasma and urinary data simultaneously (Fig. 3). The kinetic urinary $3 \mathrm{MH}$ curve shown in Fig. 3 was similar to the accumulative recovery of radiolabelled-3MH described by Harris \& Milne (1980), in whose work the majority of tracer is excreted during the first $24 \mathrm{~h}$ and excretion is gradual thereafter. Model variables and steady-state masses and transport rates were obtained and are presented in Table 3. The steady-state values obtained for this model were very similar to those of the previous plasma model, except that the $3 \mathrm{MH}$ leaving the system was partitioned into two exits: a small urinary exit averaging 29.4 (SE $5 \cdot 1) \mathrm{nmol} / \mathrm{min}$ and a much larger exit from pool 3 averaging 172.1 (SE 4.4) nmol/min. This urinary exit accounted for only $15 \%$ of the total $3 \mathrm{MH}$ leaving the system. The de novo production rate of $3 \mathrm{MH}$ into compartment 3 was 201.6 (SE 6.0) $\mathrm{nmol} / \mathrm{min}$, which corresponded to an average fractional breakdown rate of $5.4 \% / \mathrm{d}$.

The final phase in the development of the $3 \mathrm{MH}$ kinetic model was to relate the developed kinetic models to $3 \mathrm{MH}$ production in muscle by using the enrichment of $3 \mathrm{MH}$ from muscle 


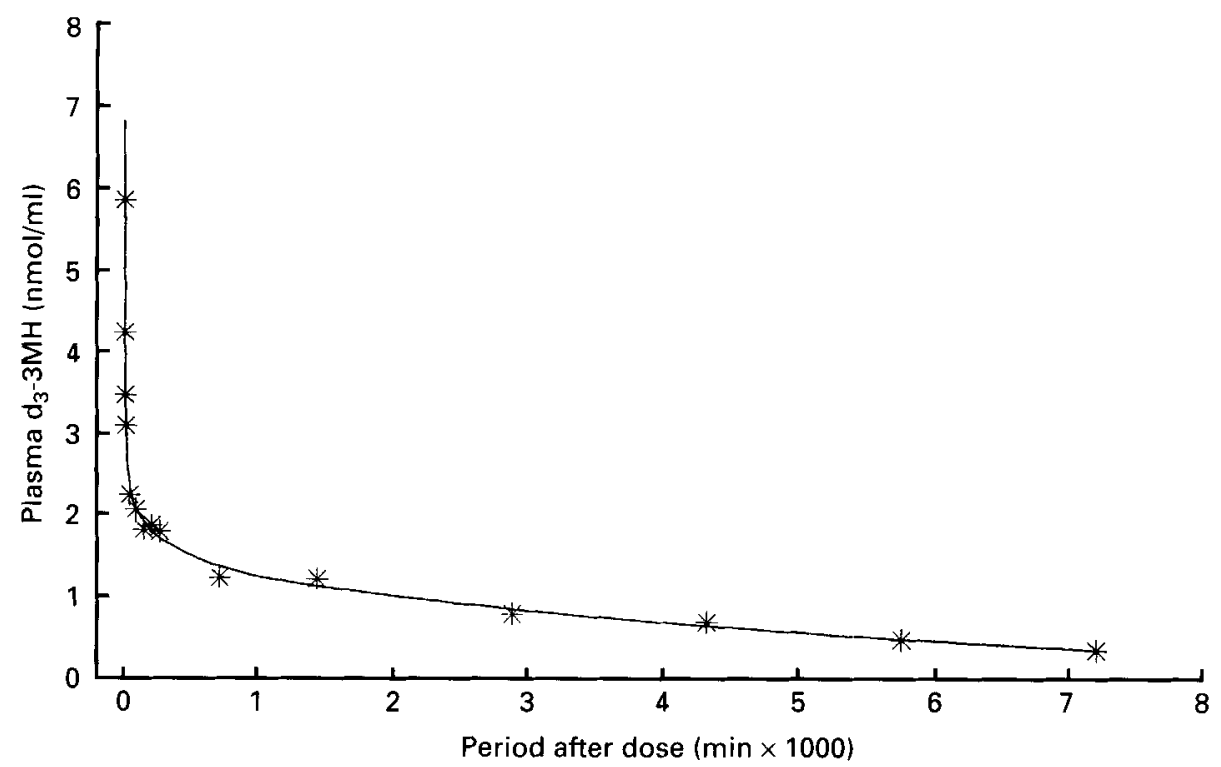

Fig. 1. The fitting of the time course of plasma $3-\left[{ }^{2} \mathrm{H}_{3}\right]$ methylhistidine $\left(\mathrm{d}_{3}-3 \mathrm{MH}\right)$ disappearance from plasma of lamb no. 9183 is presented. $\left(^{*}\right)$, Observed values; (- ${ }_{-}^{-}$), values calculated by SAAM (Boston et al. 1981), with a three exponential fit given. The residual sums of squares for a two and three exponential fit were: 3 exp 0.026 $(P<0.005), 2 \exp 0 \cdot 122 . c(T)$ is the concentration of $\mathrm{d}_{3}-3 \mathrm{MH}(\mathrm{nmol} / \mathrm{ml}$ plasma) at time $T$ (min post injection) given by $c(T)=1.5 \exp (0.0002 T)+4.4 \exp (0 \cdot 13 T)+0.91 \exp (0.004 T)$. For details of procedures, see p. 747 .

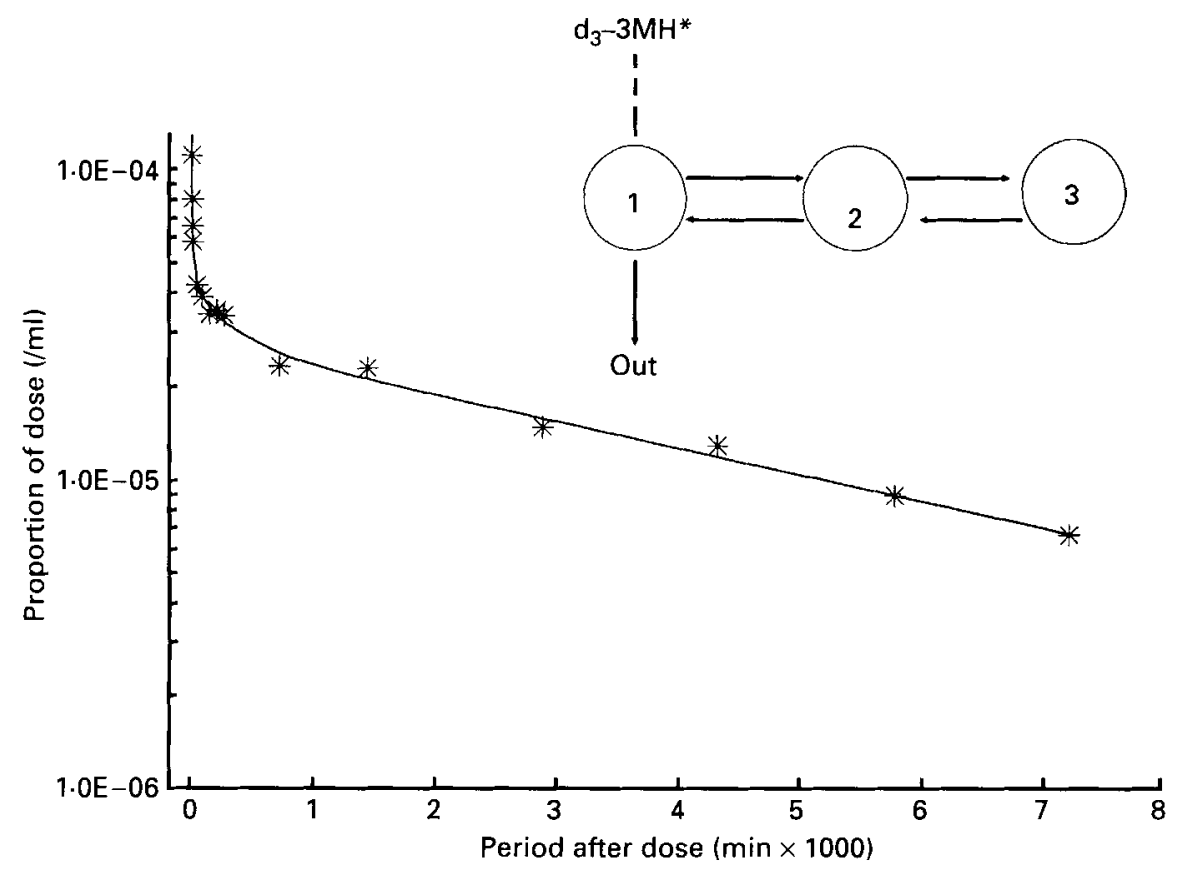

Fig. 2. Plasma $3-\left[{ }^{2} \mathrm{H}_{3}\right]$ methylhistidine $\left(\mathrm{d}_{3}-3 \mathrm{MH}\right)$ for lamb no. 9183 following an injection. The tracer $\mathrm{d}_{3}-3 \mathrm{MH}$ was converted to proportion of dose $/ \mathrm{ml}$ by dividing by the injected dose as depicted on the $y$-axis. $\left({ }^{*}\right)$, Actual measurements; $(-)$, model prediction. Also depicted is a graphical representation of the kinetic model (model A) used to describe this curve. $d_{3}-3 \mathrm{MH}$ was injected into pool 1 , and an exit was through the same pool. For details of procedures, see p. 747 . 
Table 3. Kinetic variables of 3-methylhistidine (3MH) metabolism with steady-state $3 \mathrm{MH}$ masses and transport rates for two different compartmental models in four lambs*

(Estimated variable and steady-state value means with their standard errors. Each mean is composed of four values generated by SAAM/CONSAM (Boston et al. 1981) during the final fit of the data)

\begin{tabular}{|c|c|c|c|c|}
\hline \multirow[t]{2}{*}{ Model... } & \multicolumn{2}{|c|}{$\begin{array}{c}\text { Simple plasma } \\
\text { (A } \dagger)\end{array}$} & \multicolumn{2}{|c|}{$\begin{array}{c}\text { Plasma + urine } \\
\left(\mathbf{B}_{\leftarrow}^{+}\right)\end{array}$} \\
\hline & Mean & $\mathrm{SE}$ & Mean & SE \\
\hline $\mathrm{K}(1)(\mathrm{ml})$ & 0.000138 & $0 \cdot 0000123$ & 0.00013 & 0.00001 \\
\hline Space distribution (ml) & 7380 & 607 & 7620 & 649 \\
\hline $\mathrm{L}(2,1)(\mathrm{min})$ & $0 \cdot 113$ & 0.0235 & $0 \cdot 104$ & 0.0224 \\
\hline $\mathrm{L}(1,2)(\min )$ & 0.0661 & 00150 & 0.0598 & 00144 \\
\hline $\mathrm{L}(3,2)(\mathrm{min})$ & 0.00340 & 0.000977 & 0.00331 & 0.00116 \\
\hline $\mathrm{L}(2,3)(\mathrm{min})$ & 0.00303 & 0.000241 & 0.00217 & 0.000422 \\
\hline $\mathrm{L}(0,1)(\mathrm{min})$ & 0.000804 & 0.0000738 & \multicolumn{2}{|c|}{ NA } \\
\hline $\mathrm{L}(10,1)(\mathrm{min})$ & \multicolumn{2}{|c|}{ NA } & 0.000114 & 00000256 \\
\hline $\mathrm{L}(0,3)(\mathrm{min})$ & \multicolumn{2}{|c|}{ NA } & 0.000337 & 0.0000415 \\
\hline $\mathrm{M}(1)(\mu \mathrm{mol}) \S$ & 261 & $24 \cdot 6$ & 271 & $26 \cdot 8$ \\
\hline $\mathrm{M}(2)(\mu \mathrm{mol})$ & 478 & $86 \cdot 3$ & 503 & 96.0 \\
\hline$M(3)(f \mathrm{~mol})$ & 473 & 83.0 & 543 & 90.9 \\
\hline $\mathrm{U}(2)(\mu \mathrm{mol} / \mathrm{min})$ & 0.205 & 0.00360 & $0 \cdot 201$ & 0.00600 \\
\hline $\mathrm{R}(2,1)(\mu \mathrm{mol} / \mathrm{min})$ & $28 \cdot 8$ & $5 \cdot 14$ & $27 \cdot 3$ & $5 \cdot 03$ \\
\hline $\mathrm{R}(1,2)(\mu \mathrm{mol} / \mathrm{min})$ & $29 \cdot 0$ & $5 \cdot 14$ & $27 \cdot 3$ & $5 \cdot 03$ \\
\hline $\mathrm{R}(3,2)(\mu \mathrm{mol} / \mathrm{min})$ & 1.42 & $0 \cdot 224$ & $1 \cdot 39$ & 0.331 \\
\hline $\mathrm{R}(2,3)(\mu \mathrm{mol} / \mathrm{min})$ & 1.42 & $0 \cdot 224$ & 1.21 & $0 \cdot 327$ \\
\hline $\mathrm{R}(0,1)(\mu \mathrm{mol} / \mathrm{min})$ & 0.205 & 0.00360 & \multicolumn{2}{|c|}{ NA } \\
\hline $\mathrm{R}(0,3)(\mu \mathrm{mol} / \mathrm{min})$ & \multicolumn{2}{|c|}{ NA } & $0 \cdot 172$ & 0.00440 \\
\hline $\mathrm{R}(10,1)(\mu \mathrm{mol} / \mathrm{min})$ & \multicolumn{2}{|c|}{ NA } & 0.029 & 0.00510 \\
\hline
\end{tabular}

* For details of procedures, see p. 747.

$\dagger$ Model A is a simple three-compartmental plasma model with one exit from the system from compartment I ( $(0,1))$; see Fig. 2.

$\ddagger$ Model B, which is a plasma-urinary model with two exits from the system, is a modification of the simple plasma model in which the accumulative urinary 3-methylhistidine kinetic data were included as an exit from compartment $1(\mathrm{~L}(10,1))$, and a second exit from compartment $3(\mathrm{~L}(0,3))$ was included; see Fig. 3.

$\S \mathrm{L}(\mathrm{I}, \mathrm{J})$, Proportion of material transported from compartment $\mathrm{J}$ to $\mathbf{I}$ per unit time (proportion/min); $\mathrm{R}(\mathrm{I}, \mathbf{J})$, transport of tracee (natural $3 \mathrm{MH}$ ) from compartment $\mathbf{J}$ to $\mathbf{I}$ per unit time (nmol $/ \mathrm{min}$ ) under steady-state conditions; $\mathrm{U}(\mathrm{I})$, entry of tracee into compartment I from outside of the model per unit time (nmol/min). The de novo production of unlabelled $3 \mathrm{MH}$ from breakdown of actin and myosin proteins into intracellular muscle pool under steady-state conditions; $\mathrm{M}(\mathrm{I})$, mass of tracee (unlabelled $3 \mathrm{MH}$ ) in compartment $\mathrm{I} ; \mathrm{K}(\mathrm{I})$, proportionality constant associated with compartment I. CONSAM assumes that a component number is specified under an $\mathrm{H}$ DATa header statement in the input file, and it will automatically multiply the category associated with this component by $\mathrm{K}(\mathrm{I})$ to calculate QC(I). QC(I) is CONSAM's notation for calculated values. Data associated with a component, I, are called $\mathrm{QO}(\mathrm{I}) ; \mathrm{K}(\mathrm{I})$ represented the inverse of the space of distribution. The number of compartments in the model is arbitrary and reflects simply the choices of compartment numbers made during the development of the model; NA, not applicable.

Steady-state values were initiated by multiplying the average plasma concentration of $3 \mathrm{MH}$ by the space of distribution.

biopsies of the longissimus dorsi. The kinetic data from muscle were entered into either compartment 2 or compartment 3 by using the plasma-urinary kinetic model with two exits (Fig. 4). When the muscle kinetic data were entered into compartment 2 , the values at 12 , 60 and 300 min calculated by the model overestimated the observed values at these same times and produced identical values at 1440 and $4320 \mathrm{~min}$. When the data were entered into compartment 3 , however, the model underestimated the early time-points and slightly overestimated the latter time-points. 


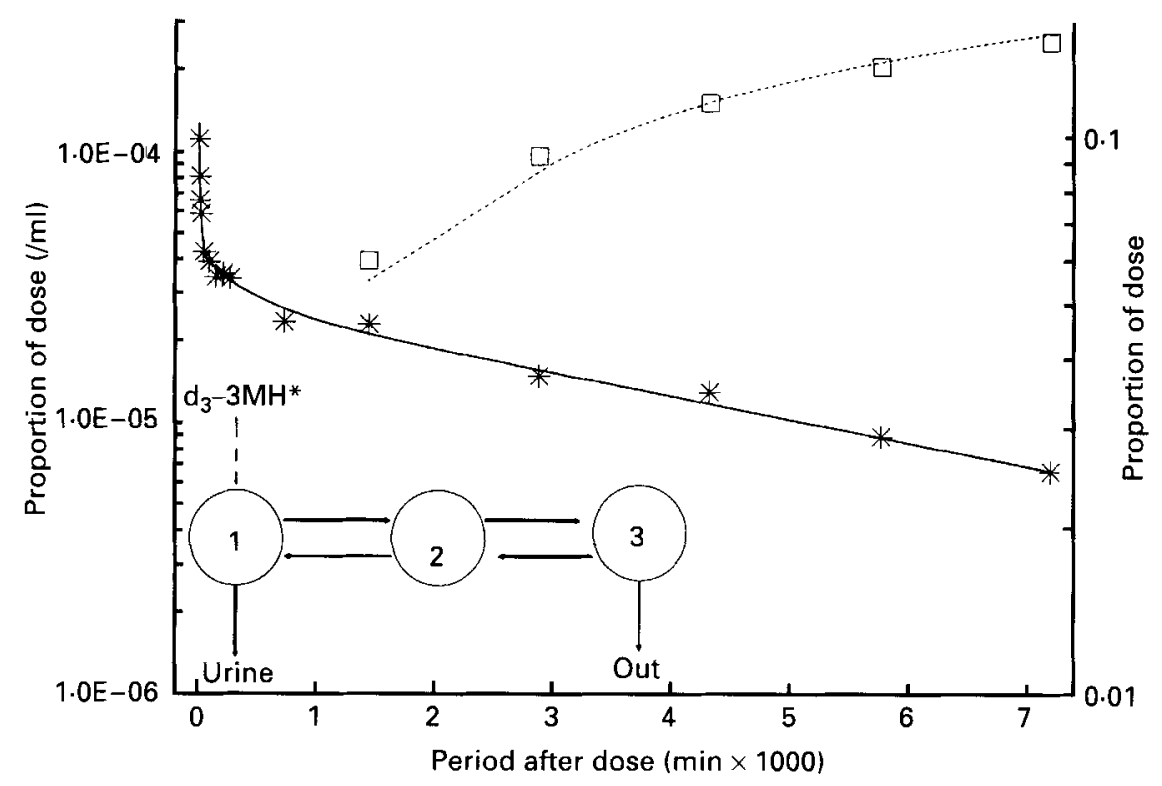

Fig. 3. The simultaneous fit of plasma and urine kinetic data from lamb no. 9183. Plasma is represented as a proportion of dose of $3-\left[{ }^{2} \mathrm{H}_{3}\right]$ methylhistidine $\left(\mathrm{d}_{3}-3 \mathrm{MH}\right)$ per $\mathrm{ml}(-)$, while the urine is represented as a proportion of dose of $\mathrm{d}_{3}-3 \mathrm{MH}(-\cdots)$. Also illustrated is the proposed model (model $\mathrm{B}$ ) compatible with the data, in which urine exit was from pool 1 , and another exit occurred from pool 3. For details of procedures, see p. 747 .

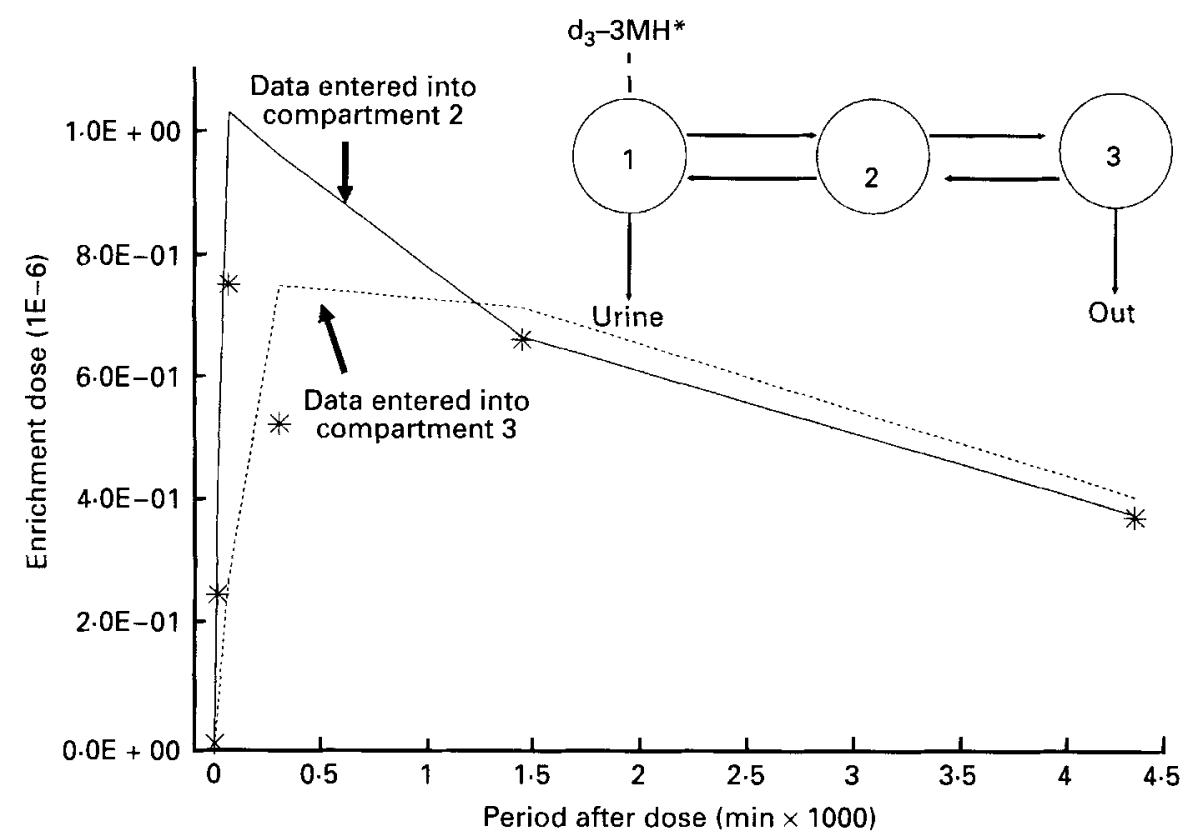

Fig. 4. The predicted enrichment of $3-\left[{ }^{2} \mathbf{H}_{3}\right]$ methylhistidine in muscle when entered either into compartment 2 $(--)$ or $3(\cdots)$ by using the proposed model B (plasma and urine kinetic model, see Fig. 3; lamb no. 9186). *, Actual observed measurements. For details of procedures, see p. 747. 
Table 4. Lamb status and natural 3-methylhistidine (3MH) measurements

\begin{tabular}{|c|c|c|c|c|c|c|c|c|}
\hline \multirow[t]{2}{*}{$\begin{array}{l}\text { Lamb no... } \\
\text { Sex }\end{array}$} & \multicolumn{2}{|c|}{$\begin{array}{c}9173 \\
\hat{\sigma}\end{array}$} & \multicolumn{2}{|c|}{$\begin{array}{c}9183 \\
0\end{array}$} & \multicolumn{2}{|c|}{$\begin{array}{c}9186 \\
\delta\end{array}$} & \multicolumn{2}{|c|}{$\begin{array}{c}9169 \\
q\end{array}$} \\
\hline & Mean & $\mathrm{SE}$ & Mean & SE & Mean & $\mathrm{SE}$ & Mean & $\mathrm{SE}$ \\
\hline Weight $(\mathrm{kg})$ & $25 \cdot 9$ & & $27 \cdot 3$ & & $25 \cdot 0$ & & $25 \cdot 0$ & \\
\hline Plasma 3MH $(\mathrm{nmol} / \mathrm{ml})^{*}$ & 38.5 & $0 \cdot 2$ & $30 \cdot 3$ & 0.2 & $32 \cdot 8$ & $0 \cdot 1$ & $41 \cdot 2$ & $0 \cdot 2$ \\
\hline Urinary $3 \mathrm{MH}$ production $(\mathrm{nmol} / \mathrm{min})$ & $22 \cdot 1$ & 1.4 & $38 \cdot 6$ & $4 \cdot 5$ & $26 \cdot 1$ & 1.9 & $17 \cdot 6$ & $1 \cdot 7$ \\
\hline $\begin{array}{l}\text { Model calculated urinary } 3 \mathrm{MH} \\
\text { production }(\mathrm{nmol} / \mathrm{min})^{*}\end{array}$ & $23 \cdot 4$ & $1 \cdot 1$ & $41 \cdot 4$ & $1 \cdot 3$ & $34 \cdot 4$ & $1 \cdot 3$ & $18 \cdot 7$ & $1 \cdot 0$ \\
\hline $\begin{array}{l}\text { Model calculated } 3 \mathrm{MH} \text { production } \\
\text { (nmol/min) } \ddagger\end{array}$ & $191 \cdot 7$ & $63 \cdot 8$ & $205 \cdot 8$ & $5 \cdot 7$ & $213 \cdot 2$ & 6.7 & $205 \cdot 5$ & $7 \cdot 1$ \\
\hline Muscle $3 \mathrm{MH}(\mathrm{nmol} / \mathrm{g}) \ddagger$ & 34.5 & $4 \cdot 7$ & $29 \cdot 0$ & $5 \cdot 7$ & $20 \cdot 4$ & $1 \cdot 3$ & $33 \cdot 1$ & 4.5 \\
\hline
\end{tabular}

* Urinary $3 \mathrm{MH}$ production was calculated from a compartmental model (model B) based on plasma and urinary kinetics of $3-\left[{ }^{2} \mathrm{H}_{3}\right]$ methylhistidine.

$\dagger 3 \mathrm{MH}$ production calculated from a compartmental model (model A) based on plasma kinetics of 3 $\left[{ }^{2} \mathrm{H}_{3}\right]$ methylhistidine.

$\ddagger$ Non-protein-bound $3 \mathrm{MH}$ in muscle.

A summary of $3 \mathrm{MH}$ kinetics and measurement of physiological characteristics are shown in Table 4. The mean plasma concentration was 35.7 (SE 2.5) nmol $/ \mathrm{min}$, while muscle was $29 \cdot 2$ (SE $3 \cdot 2) \mathrm{nmol} / \mathrm{g}$ (wet) weight of muscle. The urinary production rate estimated from model B was $26 \cdot 1$ (SE 4.5) $\mathrm{nmol} / \mathrm{min}$. The actual urinary $3 \mathrm{MH}$ production rate was similar to the values calculated from model B, that is $29.4 \mathrm{nmol} / \mathrm{min}$ (Table 3 ). Whereas urinary recovery of $3 \mathrm{MH}$ is incomplete, a compartmental model can be used to calculate kinetically a de novo production rate based on plasma kinetics (Table $3 ; 205 \mathrm{nmol} / \mathrm{min}$ ).

\section{DISCUSSION}

The major objectives of the present study were to show that the $3 \mathrm{MH}$ kinetics of a stable isotope could be described by a compartmental model and to determine whether a de novo production rate of the tracee could be estimated. This method is of value to estimate the fractional breakdown rate of muscle protein because urinary $3 \mathrm{MH}$ is invalid for use in species such as sheep and pigs. Other methods for studying muscle protein degradation directly are limited, and methods are available that allow for indirect calculation of muscle degradation if the fractional accretion rate of muscle protein is known (Garlick, 1980).

We have described the in vivo kinetics of $3 \mathrm{MH}$ in lambs by means of two different models, starting with a very simple three-compartment model requiring only the sampling of plasma and thence to a model requiring the sampling of plasma and urine. The simple plasma model (model A) and the more complex plasma-urine model (model B) gave nearly identical results, demonstrating the usefulness and accuracy of the simple plasma model. In addition, the biopsies from the longissimus dorsi were used for representing the total skeletal musculature from which $3 \mathrm{MH}$ is primarily produced. These findings used in a simulation of the plasma-urinary model forced skeletal muscle to be the only source of $3 \mathrm{MH}$ produced de novo. However, it is thought the skin and intestines may also contribute $10-15 \%$ of the daily 3MH produced (Nishizawa et al. 1977; Young \& Munro, 1978; Harris, 1981; Millward \& Bates, 1983). Therefore, a lower production rate could be expected for the model when muscle is forced to be the only source of de novo production.

The models were constructed based on previous knowledge of $3 \mathrm{MH}$ metabolic pools in sheep (Harris \& Milne, 1980). It had been demonstrated that only a small percentage of 
$3 \mathrm{MH}$, which is released from actin and myosin, is actually excreted in the urine, with the remaining majority retained as balenine in muscle. It was assumed that the tracer was initially distributed into a plasma plus extracellular water space of compartment 1 , which had an exit into a urine pool (compartment 10). This assumption was based on the space of distribution of compartment 1 (K(1), Table 3) which was 7381 and 7619 for model A and $\mathrm{B}$ respectively. This space of distribution for compartment 1 was $30 \%$ of the body weight of these four lambs and would be approximately equal to the extracellular water space. Additionally, model B accurately predicted the daily excretion of $3 \mathrm{MH}$ in the urine: $26 \cdot 1$ was observed compared with $29 \cdot 4 \mathrm{nmol} / \mathrm{min}$ predicted. Compartments 2 and 3 are most likely to be intracellular pools of free non-protein-bound $3 \mathrm{MH}$, with a second exit from pool 3 being most likely into a balenine 'sink'. The second exit was assumed to be an exit into a balenine pool that was thought to turn over very slowly or not at all during the duration of the study because balenine seems to accumulate in the muscle of sheep. Nevertheless, when the concentration of free $3 \mathrm{MH}$ in the longissimus dorsi was extrapolated to the total musculature of the lambs the observed pool size of muscle-free $3 \mathrm{MH}$ was only half the model calculated compartment size of either 2 or 3 . This might be expected if the enrichment of our tracer in muscle differed between muscles or groups of muscles as the longissimus dorsi was used to represent the whole musculature, and the contribution of $3 \mathrm{MH}$ from smooth muscle actin to the size of compartments 2 and 3 must also be taken into account.

The structural configurations of these models are not unique, and alternative arrangements may also be compatible with the data. It was possible with simple plasma model A to place the exit from the system at any of the three compartments and to obtain identical agreement between observed and model calculated values. Again with model $B$ the second exit could be placed at any of the three compartments. It is also possible to enter the muscle response into either compartment 2 or 3 as a single metabolic pool and to obtain a solution. The present models represent a framework and methodological approach describing steady-state $3 \mathrm{MH}$ kinetics in the whole animal and constitute a working theory for testing by further experimentation with designs altering muscle protein breakdown.

In conclusion, the rate of $3 \mathrm{MH}$ production is an important tool in understanding the regulation of muscle protein degradation. The advantages of these models are that (1) it does not necessitate quantitative urine collection (plasma model); (2) it reduces error due to the frequency of plasma sampling $v$. the infrequency of urine collection in the other models; (3) it measures the total production rate independent of the determination of free or conjugated forms; (4) it gives information about pool size and transfer rates; (5) it does not require restraint of the animals for long periods. The model does, however, need further validation as a method for estimating $3 \mathrm{MH}$ production in other species.

This work was supported in part by a grant in aid from Eli Lilly \& Co. and by the Iowa Agriculture and Home Economics Experiment Station. The authors are grateful for the skilful assistance of Debra Webb, Luvern Wiskus, Brennan Smith, Becky Sperling, and Jerry Joyce.

\section{REFERENCES}

Berman, M. \& Weiss, M. F. (1978). SAAM Manual. US Department of Health, Education and Welfare Publication no. (NIH) 78-180. Washington, DC: US Government Printing Office.

Boston, R. C., Grief, P. C. \& Berman, M. (1981). Conversational SAAM - an inter-reactive program for kinetic analysis of biological systems. Computer Programs in Biomedicine 13, 111-119.

Garlick, P. J. (1980). Assessment of protein metabolism in the intact animal. In Protein Deposition in Animals [P. J. Buttery and D. B. Lindsay, editors]. London: Butterworths.

Harris, C. I. (1981). Reappraisal of the quantitative importance of non-skeletal-muscle source of $\mathrm{N}$-taumethylhistidine in urine. Biochemical Journal 194, 1011-1014. 
Harris, C. I. \& Milne, G. (1980). The urinary excretion of $\mathrm{N}^{7}$-methyl histidine in sheep: an invalid index of muscle protein breakdown. British Journal of Nutrition 44, 129-140.

Harris, C. I. \& Milne, G. (1981). The urinary excretion of $\mathrm{N}^{3}$-methyl histidine by cattle: validation as an index of muscle protein breakdown. British Journal of Nutrition 45, 411-422.

Harris, C. I. \& Milne, G. (1987). The identification of the N-methyl histidine-containing dipeptide, balenine, in muscle extracts from various mammals and the chicken. Comparative Biochemical Physiology 86B, $273-279$.

Harris, C. I., Milne, G., Lobley, G. E. \& Nicholas, G. A. (1977). 3-Methylhistidine as a measure of skeletal-muscle protein catabolism in the adult New Zealand white rabbit. Biochemical Society Transactions 5, 706-708.

Johnson, P., Harris, C. I. \& Perry, S. V. (1967). 3-Methylhistidine in actin and other muscle proteins. Biochemical Journal 105, 361-370.

Millward, D. J. \& Bates, P. C. (1983). 3-Methylhistidine turnover in the whole body, and the contribution of skeletal muscle and intestine to urinary 3-methylhistidine excretion in the adult rat. Biochemical Journal 214, $607-615$.

National Research Council (1985). Nutrient Requirements of Sheep. Washington, DC: National Academy Press.

Nishizawa, N., Noguchi, T. \& Hareyama, S. (1977). Fractional flux rates of $\mathbf{N}^{\top}$-methylhistidine in skin and gastrointestine: the contribution of these tissues to urinary excretion of $\mathrm{N}^{\top}$-methylhistidine in the rat. British Journal of Nutrition 38, 149-151.

Young, V. R., Alex, S. D., Baliga, B. S., Munro, H. N. \& Muecke, W. (1972). Metabolism of administered 3methylhistidine: lack of muscle transfer ribonucleic acid charging and quantitative excretion as 3methylhistidine and its N-acetyl derivative. Journal of Biological Chemistry 217, 3592-3600.

Young, V. R., Haverberg, L. N., Bilmazes, C. \& Munro, H. N. (1973). Potential use of 3-methylhistidine excretion as an index of progressive reduction in muscle protein catabolism during starvation. Metabolism 22, 1429-1436.

Young, V. R. \& Munro, H. N. (1978). Nt-Methylhistidine (3-methylhistidine) and muscle protein turnover: An overview. Federation Proceedings 37, 2291-2300. 